\title{
Effects of the Brazilian tax reform plans on the tobacco market
}

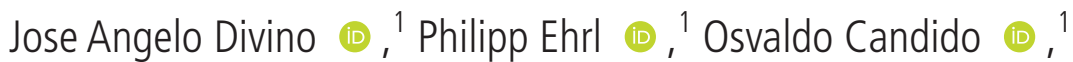 \\ Marcos Aurelio Pereira Valadao (10 ${ }^{2}$
}

\begin{abstract}
- Additional supplemental material is published online only. To view, please visit the journal online (http://dx.doi. org/10.1136/tobaccocontrol2021-056822)
\end{abstract}

${ }^{1}$ Graduate Program of Economics, Catholic Univeristy of Brasilia, Brasilia, DF, Brazil ${ }^{2}$ School of Public Policy and Government, Getulio Vargas Foundation, Brasília, Distrito Federal, Brazil

Correspondence to Professor Jose Angelo Divino, Graduate Program of Economics, Catholic University of Brasilia, Brasilia, DF, Brazil; jangelo@p.ucb.br

Received 31 May 2021 Accepted 6 August 2021
Check for updates

(C) Author(s) (or their employer(s)) 2021. No commercial re-use. See rights and permissions. Published by BMJ.

To cite: Divino JA, Ehrl P, Candido 0, et al. Tob Control Epub ahead of print: [please include Day Month Year]. doi:10.1136/

tobaccocontrol-2021-056822

\begin{abstract}
Background There has been an intense debate in the Brazilian National Congress on how to reform the country's tax system on consumption. This paper investigates the effects of the tax reform under the Constitutional Amendment Bill 45/2019 on cigarette prices, consumption and tax collection. The reform will introduce a new goods and services tax (GST) and tobacco excise tax (TET).

Methods The micro data from the National Household Sample Survey (PNAD) of 2008 and the National Health Survey (PNS) of 2013 are inputs in the simulation in order to determine the smoking behaviour and consumer responses to price changes as accurately as possible across the different Brazilian states. We developed three scenarios for the tobacco tax reform and their effects on cigarette prices, smoking behaviour and tax collection. We also estimate the size of the illicit cigarette market by Brazilian state and simulate the impacts of a 10\% reduction in its market share.
\end{abstract}

Findings Overall, we found that a GST of $27 \%$ and a TET of either $51 \%, 56 \%$ or specific 3.89 BRL per pack would lead to considerably higher cigarette prices, lower cigarette consumption and, above all, an increase of cigarette tax collection between $8 \%$ and $27 \%$ depending on the state. A discretionary $10 \%$ reduction in the illicit market would add about $8.5 \%$ of extra tax collection per year to the country.

Conclusions The simulated scenarios demonstrated that, to keep the cigarette prices at least at the same level as those in the current tax scheme, TET should be no less than $77.85 \%$ of the retail price. This means that any politically feasible tax reform should result in higher cigarette prices and a reduction in cigarette consumption. Considering the nationwide effect, in all scenarios, the total increase in tobacco tax revenue is around $8.5 \%$ or 1.5 billion BRL per year. This extra revenue is highly desirable in an environment of chronic fiscal imbalance and the COVID-19 pandemic crisis.

\section{INTRODUCTION}

Over the past years, Brazil has significantly reduced the prevalence of smoking, from $34.8 \%$ in 1989 to approximately $10.5 \%$ in the Brazilian state capitals in $2019 .{ }^{12}$ This dramatic decrease can be attributed to the implementation of strong tobacco control policies, including smoking restrictions, advertising regulations, cutting economic incentives to tobacco farming and, of course, tobacco taxation.

During 2019 and 2020, there have been important discussions about a constitutional tax reform in Brazil. This subject has been on the table for the last 20 years, especially regarding the highly complex system of consumption taxes. In addition to the proposals under consideration by the Congress, several organisations (eg, labour unions, non-governmental organisations) and the National Committee of State Finance Secretaries and the Federal District (Comsefaz) have developed reform proposals by themselves and are widely debating the issue. There are also two constitutional amendment bills (also called constitutional amendment proposal-PEC) for tax reform whose processing is relatively more advanced in the National Congress. More recently, on 21 July 2020, the Executive Power sent a Bill of Law to the Congress, dealing specifically with the PIS/COFINS (a federal consumption tax levied on the company's turnover) and intending to simplify these contributions (PIS (Contribution for the Social Integration Programme) and COFINS (Contribution for Financing Social Security) are levied on all the production and commercialisation chains; for cigarettes, the PIS/COFINS is subject to a special regime called tax substitution). The proposal of the Bill of Law n. $3887 / 2020$ is to replace the current PIS/ COFINS by a general tax on consumption, named CBS (Social Contribution on Operations with Goods and Services), without changing any other taxes, namely IPI (federal consumption tax levied only on manufactured products) and ICMS (state tax levied on goods and services tax (GST)).

Constitutional amendment bills 45/2019 and $110 / 2019$ intend to simplify the tax scheme by unifying different federal, state and local taxes at the federal level. The plan includes a proposal to replace the subnational ICMS, the local ISS (a local tax on services), the IPI, and the PIS/COFINS with a unique and harmonised federal VAT-type tax, the GST (there are other aspects that are not relevant for this research, whose focus is on cigarette taxation). In addition, there will be a selective tax (excise tax) on selected goods such as tobacco, alcoholic beverages and others. When levied on tobacco, this tax is named the tobacco excise tax (TET). These are the proposals that may effectively result in a change in the tax system at both national and subnational levels and therefore affect cigarette taxation and tobacco tax revenue as well. The Constitutional Amendment 45/2019 is the more likely to be approved, given the support from the House of Representatives.

This paper analyses the effects of a tobacco tax reform, implied by the Constitutional Amendment $45 / 2019$, at the national and subnational levels in Brazil. The analysis focuses on a tax reform that harmonises tax rates across Brazilian states, and 
estimates its impact on cigarette prices, consumption and tax revenue. We also investigate the effects on these variables of an exogenous reduction in the share of the illicit cigarette market by an illustrative $10 \%$.

In all tax reform scenarios, the cigarette tax burden would increase across the Brazilian states. As a result, the aggregate tax revenue and the average price for low price brands and for premium brands would also increase. Cigarette consumption would substantially decrease in all scenarios when compared with the baseline, for both low price and premium brands. Thus, the simulation results indicate that the tax reform is a great opportunity for the country to increase cigarette prices, reduce cigarette consumption and raise cigarette tax collection.

\section{METHODS}

The present section provides a concise summary of the methods and assumptions used in the following simulations. Online supplemental appendices $\mathrm{A}-\mathrm{C}$ report further details about the data, econometric estimations, tax scenarios specifications and the price adjustment mechanism (The simulations consider a partial equilibrium model focused only on the cigarette market. There are no dynamic effects over time nor a general equilibrium structure behind the simulations. The objective is to simulate specific scenarios for the tobacco tax reform and analyse relative impacts on cigarette prices, cigarette consumption, tobacco tax burden and tobacco tax revenue, which are the key variables for the tobacco tax reform. Besides, it would be hard to capture any relevant effect of a tobacco tax reform in a CGE structure that accounts for all economic sectors, technologies and respective shares in the total output).

The pattern of cigarette consumption is derived from four representative individual surveys, the National Household Sample Survey (PNAD) of $2008^{3}$ and the National Health Survey (PNS) of $2013,{ }^{4}$ as well as the Surveillance of Risk Factors and Protection for Diseases Chronicles by Phone Survey for the year $2018,{ }^{2}$ using the latest information whenever available (Vigitel is an annual national survey of the Ministry of Health conducted by phone call to individuals randomly chosen in the 26 state capitals and the Federal District. The purpose of Vigitel is surveillance of risk and protective factors for chronic diseases; see Vigitel Brasil for the year $2018^{2}$ for further details). Based on price information, cigarettes are classified in three categories. Price category 1 (PC1) comprises all cigarettes below the official minimum price. As this minimum price is nationally binding without any exception, cigarettes purchased below this price were classified as illegal. The resulting legal market segment was divided into cheaper cigarettes and premium brands according to the median of this market segment. They were represented by price category 2 (PC2) and price category 3 (PC3), respectively.

Following an extended cost-benefit analysis of tobacco taxation in Brazil, ${ }^{5}$ estimates of the price elasticity of demand are obtained as a combination of conditional and unconditional price elasticities. Depending on the location of the consumer and on the price class of the cigarette, the total price elasticity varies between -0.38 and -0.60 . By and large, the high-price cigarette consumption is associated with a more sensitive consumption adjustment to price changes.

The simulations are derived according to the following steps:

1. Baseline scenario: Based on the smoking behaviour of the Brazilian population, the size of the illegal market is calibrated such that, under the current tax legislation, the model replicates the actual tobacco tax collection in 2018 .
2. Reform scenarios: The tobacco tax structure is adjusted according to the proposed Constitutional Amendment Bill $45 / 2019$ and the specific values of the new tax components that define the overall tax burden of cigarettes are chosen according to specific political criteria. Taking into account the price elasticity estimates, the simulations outcomes illustrate how cigarette consumers adjust consumption to the new after-reform cigarette prices. The major concern surrounding the tax reform in Brazil is to avoid overall loss of tax collection. Under this premise, in scenario I, a TET is chosen such that no Brazilian state faces any tax revenue loss. Additionally, since increasing tobacco tax is regarded as the most successful antismoking public policy, scenario II simulates the highest TET under the condition that no state experiences any tax revenue loss. Lastly, scenario III considers a mixed tax scheme where a specific tax component is charged by cigarette pack instead of a pure ad valorem tax structure used in scenarios I and II.

An explicit assumption in the reform scenario simulations is that, once the size of the illicit market is adjusted in the baseline scenario, it remains constant. This assumption is plausible because the official minimum price is not under discussion in the Constitutional Amendment Bills, and, therefore, it is likely to remain at the current level. Nevertheless, in order to show how this assumption affects tax revenue collection under the new after-reform tax scheme, we include an additional exercise where the size of the illicit market is allowed to change exogenously in a sensitivity analysis. In this case, we assume that the reduction in the illicit market is equally distributed across price categories as consumption of both, cheaper cigarettes and premium brands, increases.

\section{TAX REFORM SCENARIOS' RESULTS AND DISCUSSION Baseline scenario}

The total tax revenue collected from tobacco-related products in 2018 was about 13.5 billion BRL. This value corresponds to about $0.6 \%$ of the total tax revenue and about $0.19 \%$ of Brazil's GDP, with $0.11 \%$ going to the federal tax authorities and the remaining $0.08 \%$ to the 26 states and Federal District. Unfortunately, Receita Federal does not release the tax revenue for each Brazilian state. Thus, the model can only be calibrated in the baseline scenario to match the aggregate tobacco tax revenue. According to these numbers, the average tax burden of a cigarette pack was $72.8 \%$ in 2018 , with an SD of $4.17 \%$.

The sample was adjusted to account for the under-reported data in PNS and PNAD and the rising share of illegally purchased cigarettes since 2014 according to the Vigitel Survey for the year $2018 .^{2}$ The original estimate of the illegal market in 2013 was about $32 \%$ on average across the states. Based on the estimated number of consumers and their average consumption, the size of the illegal market required to match the observed tax revenue in 2018 , the base year, is $45 \%$. It is important to mention that this value is also found by other authors. ${ }^{67}$

Figure 1 illustrates the shares in tobacco tax collection by type of cigarette taxes across the Brazilian states. The variations in figure 1 stems from differences in both the population size and the subnational ICMS tax. The state that stands out the most by its annual tax revenue is São Paulo. First of all, it is by far the most populous state, comprising almost $25 \%$ of the Brazilian population (46 million inhabitants in 2018). Second, its tobacco tax burden is the fourth highest in the country. As a result, the state of São Paulo accounts for about $40 \%$ of the total tobacco tax collection in the country. Indeed, the three biggest tax 


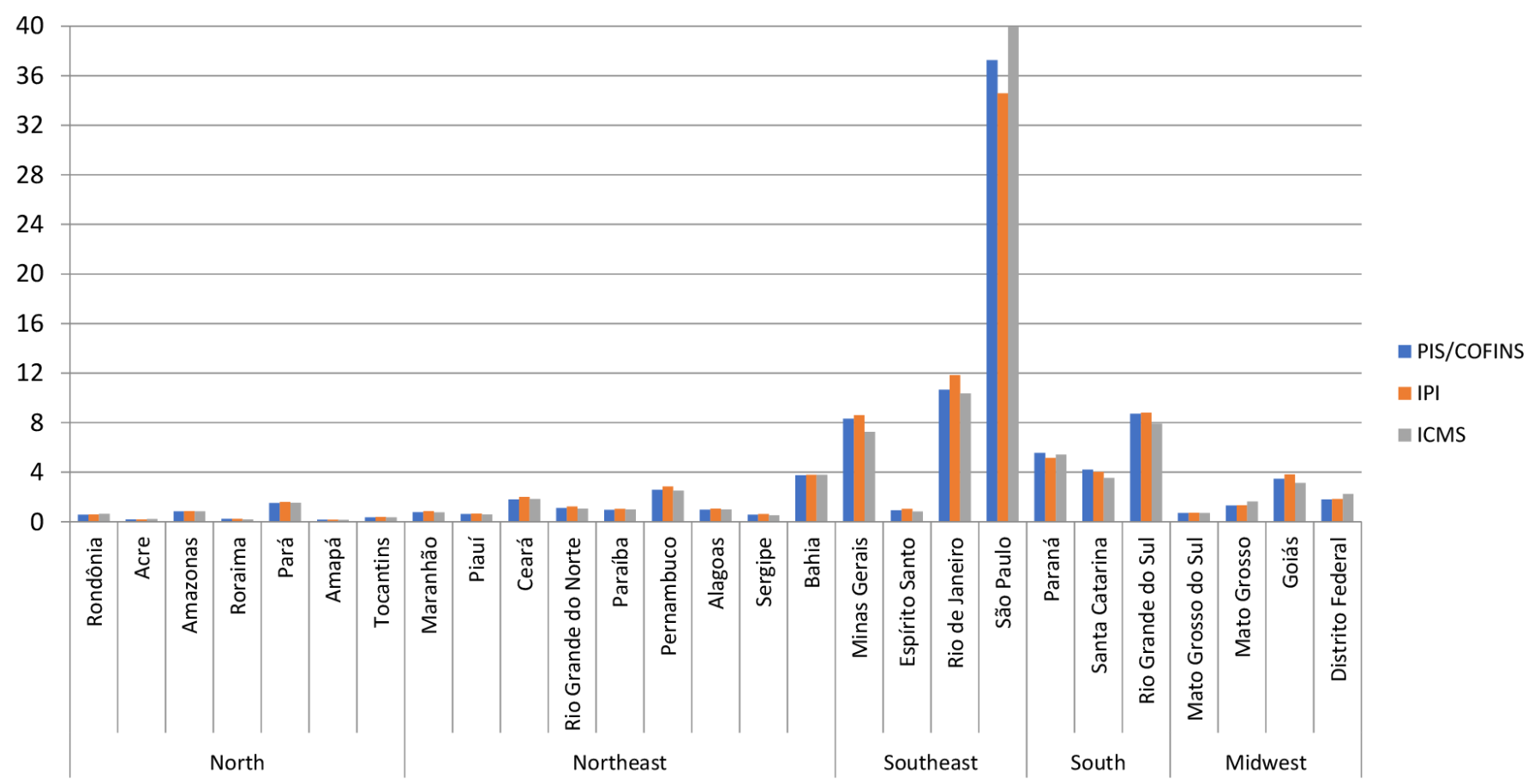

Source: Authors calculations. Notes: The PIS/COFINS is a federal consumption tax levied on the company's turnover, the IPI is a federal consumption tax levied only on manufactured products and the ICMS is a state tax levied on goods and services.

Figure 1 Shares in tobacco tax collection by regions and states-baseline scenario (in \%).

revenue collectors (São Paulo, Rio de Janeiro and Rio Grande do Sul) account for almost $57 \%$ of the total tobacco tax revenue in the country, considering the states' consumption of cigarettes.

\section{Constitutional Amendment 45/2019: no-tax-revenue-loss- scenario I}

The tax reform scenarios use results from Odair and Gobetti's approach, ${ }^{8}$ who estimated the neutral tax rate for the new GST and proposed a distribution of the aggregate tax rate among the subnational units as follows: a GST at federal level of $10.3 \%$ and a GST at state and municipal levels of $16.7 \%$. Therefore, there is a unique and nationwide GST of $27 \%$ charged on the retail prices of all goods and services traded in the country.

The TET that defines the no-tax-revenue-loss scenario is equal to $50.85 \%$ of the retail price, and the total tax burden is $77.85 \%$ (this cigarette tax burden results from the GST of $27.0 \%$ and the TET of $50.85 \%$ in this first scenario). Under the no-tax-revenueloss scenario, the average price increased by $34.2 \%$, resulting in a decrease in consumption by $14.0 \%$. There is also an increase of BRL3.7 billion in total revenue collection per year. The tax reform has a different impact by price category. While low cost brands increased prices by $18.3 \%$, premium brands raised it by $45.9 \%$. A similar movement was also observed in cigarette consumption, where smokers consuming low price brands reduce consumption by $9.8 \%$, while premium brand smokers reduce consumption by $25.3 \%$. Additionally, the price dispersion across Brazilian states experienced a substantial increase by more than 200\%, raising the SD for both price categories.

The state of Mato Grosso effectively defines the value of the TET because of the most unfavourable change in the tobacco tax revenue. Figure 2 shows that, in relation to the current cigarette tax revenue, Mato Grosso would face a $16.3 \%$ revenue reduction from low-price cigarettes, but an $8.4 \%$ increase in revenue from high-price cigarettes. By construction of the TET in the no-tax-revenue-loss scenario, the change in the total tax revenue is exactly zero in the state of Mato Grosso, as the negative variation in tax collection for PC2 exactly offsets the positive variation for PC3 (Instead, we could easily have simulated a 'no-loss scenario', where tax revenue within each price category would be at least zero. First, the differences between these two cases are small and, further, the no-loss scenario is easier to explain and more transparent. Second, the price categories are arbitrarily defined and serve as approximations, so it is prudent not to put too much weight on them. Third, the price decreases do not violate the current minimum price of cigarettes or any other legislation. Finally, the result also serves to raise awareness for everyone involved in the discussion about the tax reform, that falling cigarette prices can be an isolated outcome. If falling cigarette prices were to be avoided, a sufficiently high TET or additional regulation should be introduced).

Only two other federal units, namely Rondônia and the Federal District, would have falling cigarette tax revenues in one of the price categories, but this loss is more than compensated by the increase in tax revenue in the other price category. This result occurs because these two states, along with Mato Grosso, already have the highest tax burdens in the country. Thus, the reform would lead to higher tax burdens in all other federal states. In Santa Catarina, the most extreme case of lower tax burden, the tax revenue would increase by $51.2 \%$.

The observed differences across price categories even in the same state is due to the complex tax calculation that currently combines a VAT component and a fixed component for each cigarette pack, independent of its final price. Therefore, the prevailing tax burden is generally lower for high-price cigarettes. The equalisation of the tax burden in both categories thus increases prices and tax revenue relatively more for highprice brands. This change in the tax structure explains why in the Federal District, for instance, the tax burden of cigarettes in PC2 decreased by $13 \%$ while for PC3 increased by $13 \%$. Finally, 


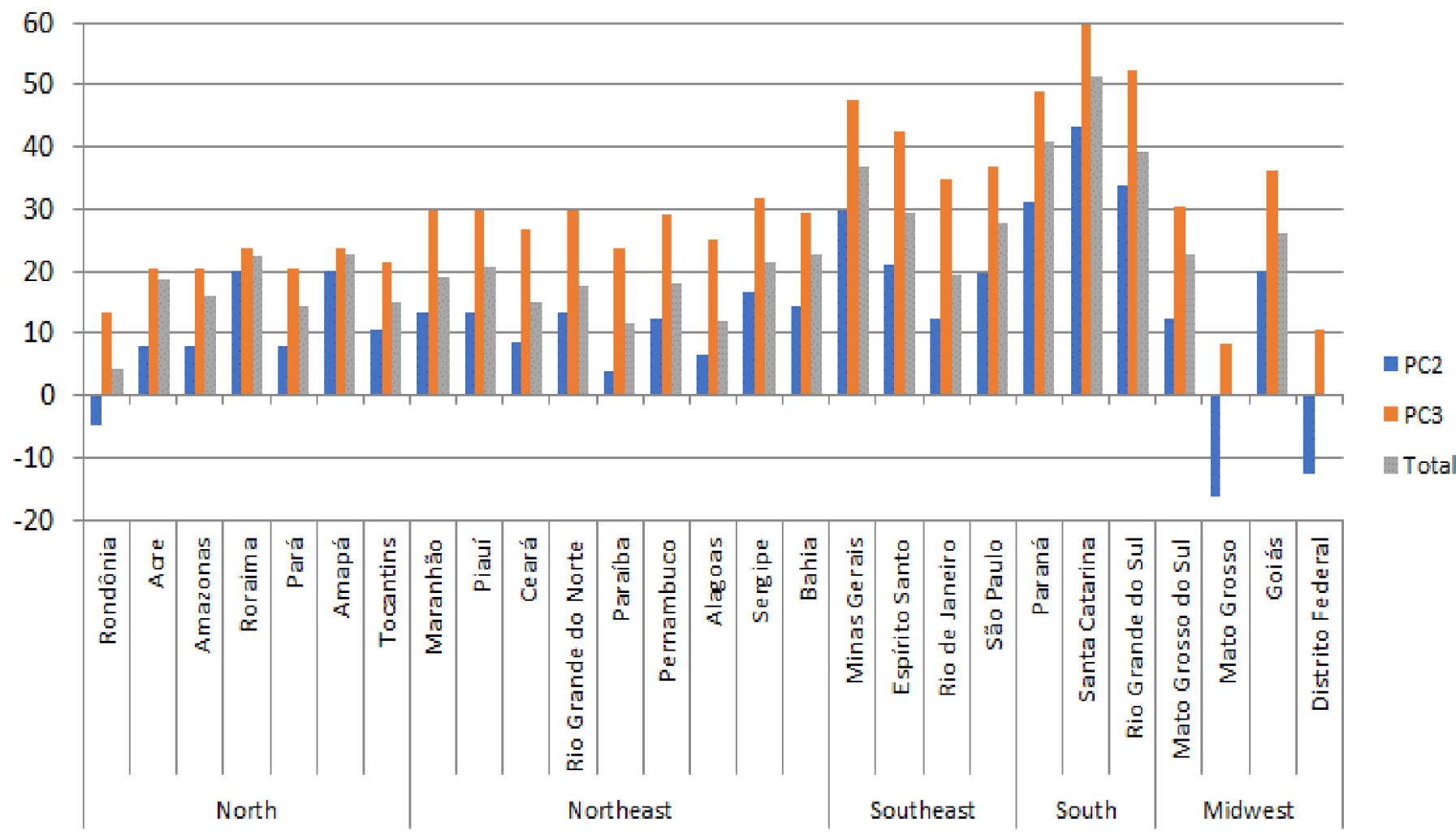

Source: Authors calculations.

Figure 2 Percentage tax revenue change by price category (PC) relative to the current tax structure-tax reform scenario I.

a lower tax burden implies lower prices, which in turn implies lower tax collection as well.

The finding that prices of cheaper cigarettes would increase less than premium brands is of major political relevance. There is a debate between several public departments in Brazil about whether a change in the current cigarette price would affect the size of the illegal cigarette market. The final report of a task force on this subject came to the conclusion that there is no substantial evidence that lower taxes would cause any relevant reduction in cigarette smuggling. ${ }^{9}$ At least, the simulations conducted here indicate that the gap between low-price and high-price cigarettes in the legal market widens. The results of the present research confirm another speculative concern of the task force that lower cigarette taxation could decrease revenue and increase consumption. As a general result, prices in the two categories of the formal market deviate further apart from each other. This result is due to the transition from a mix tax structure that combines fixed and ad valorem components to a pure ad valorem tax structure after the reform. This may lead to an increase in the price gap, which is not recommended according to the extensive discussion in the WHO's tobacco tax policy manual. ${ }^{10}$

The advantages of this tax scheme are that it is less regressive and does not require adjustment of the value of the fixed component (specific tax) over time to avoid the negative effects of inflation, which would make tobacco taxation increasingly subject to political interference. In addition, once fixed by law, the tax burden is no longer affected by changes in producer prices or inflation. Although the tax burden is uniform across federal states, the final cigarette prices could still vary among them for several reasons, including logistics costs, market characteristics and price elasticities.

In sum, the tax reform would benefit all states by resulting in higher cigarette prices, lower cigarette consumption and higher tax revenue, even though it would increase the cigarette price gap.

\section{Constitutional Amendment 45/2019: maximum-excise-tax- scenario II}

The mechanism used to obtain the results under the second reform scenario is the same as in the previous case, except that the TET rate is now set at a different value. TET is now sequentially increased up to the point where the first state would start to lose tax revenue. The resulting level for the TET is $55.95 \%$ in order to maximise tax revenue subject to the constraint that no state suffers any decrease in tobacco tax collection. Thus, the total tax burden reaches $82.95 \%$ in the second scenario (this tax burden results from $27.0 \%$ of the GST and $55.95 \%$ of the TET).

Under the maximum-excise-tax scenario, the average price increases by $74.2 \%$, resulting in a decrease in consumption of $30.8 \%$ and an increase of BRL5.4 billion in total revenue collection per year. Prices of cheaper cigarettes increase by $53.6 \%$ and consumption declines by $25.3 \%$, while for premium brands cigarettes prices climb by $89.5 \%$ and consumption decreases by $40 \%$. Similar to the previous scenario, the price dispersion increases by $290 \%$ in relation to the baseline SD for both price categories.

The explanation for the outcome that tax revenue starts to decrease after some maximum level is in line with the Laffer curve. Due to the negative price-elasticity of consumption and the proportional linkage between tax burden and consumer price, once prices are sufficiently high, falling consumption is relatively larger than the price increase. However, higher increases will result in additional revenues relative to the status quo situation. To reach the same revenue collection obtained under the current tax scheme, the tax burden should increase 


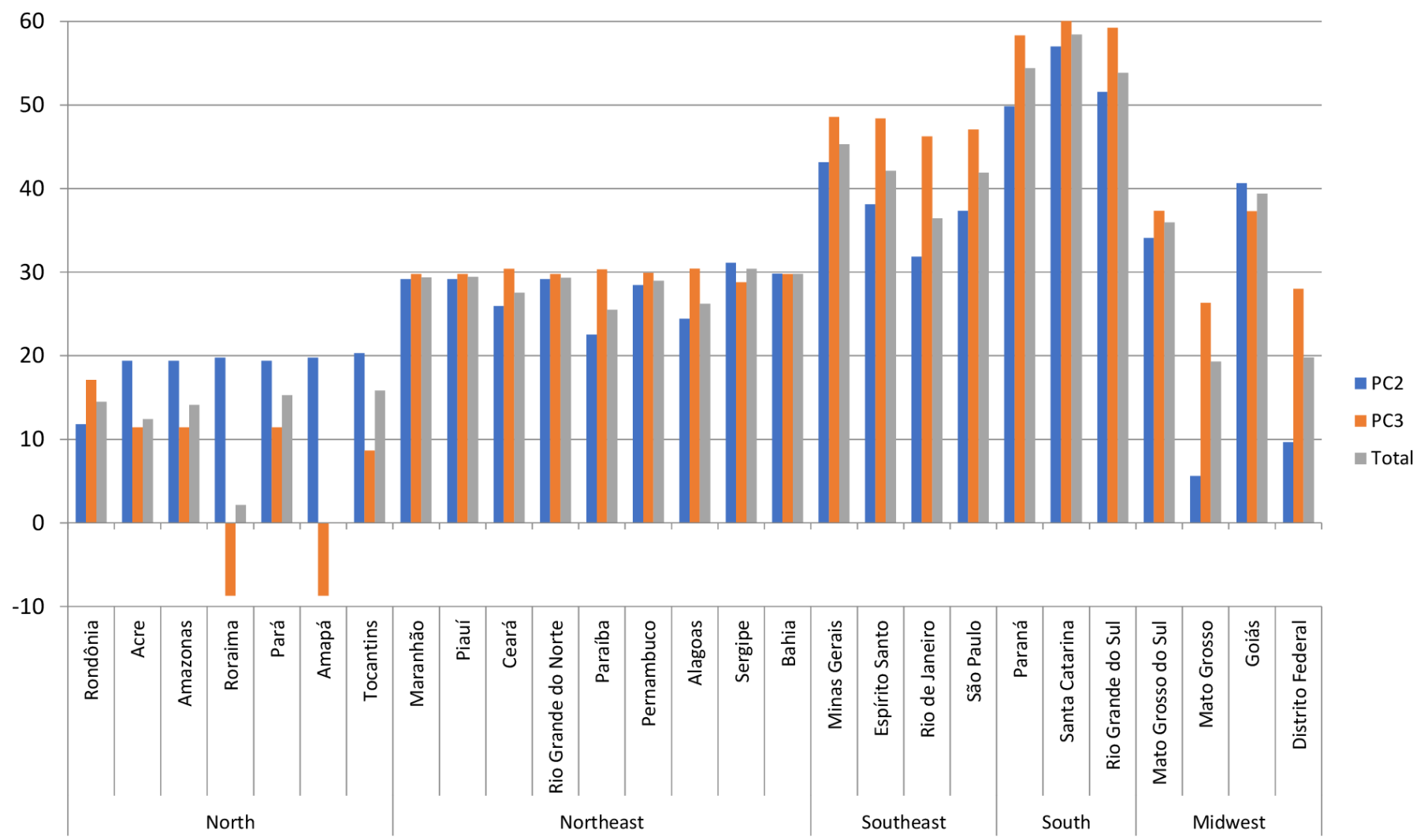

Source: Authors calculations.

Figure 3 Percentage tax revenue changes by price category $(\mathrm{PC})$ relative to the current tax structure-tax reform scenario II.

to $82.95 \%$. This means that any tax increasing up to this level would result in increase in the overall revenue collection.

Figure 3 illustrates that the change in tax revenue becomes negative for the premium cigarette brands because the relative price increase is more pronounced. The state that defines the value of the TET in this second scenario is Amapá, where a TET of $55.95 \%$ implies that the revenue loss in premium brands exactly offsets the tax revenue gain in cheaper cigarettes so that the overall change in tax collection is null. Another state that has a similar prereform price and tax structure and thus experiences falling tax revenue for premium brands after the reform is Roraima.

Given that the TET is higher than in the previous scenario, prices and tax revenues, in aggregate, are also higher. However, the configuration of percentage change in tax collection is quite distinct across the two scenarios. In fact, the relative tobacco tax revenue decreases $8.7 \%$ for the cheaper cigarettes in Roraima and Amapá but increases by about $60 \%$ for premium brands in Santa Catarina and the other two states in the southern region. In general, the maximum-excise-tax reform scenario does not widen the price gap between the two price categories as much as under the tax reform scenario I. In the northern states, where the consumption of premium cigarette brands is relatively higher, the reform would even narrow the price discrepancy.

\section{Specific federal excise tax on cigarettes with no-tax-revenue- loss-scenario III}

In this scenario, a specific tax component is chosen such that none of the Brazilian states experiences any loss in tax collection. The specific value obtained for TET under this constraint is BRL3.89 per pack. In this scenario, the average price increases by $11.5 \%$, resulting in a decrease in consumption of $4.6 \%$. This results in an increase of BRL1.1 billion in total revenue collection per year. This tax reform scenario has distinct impacts by price category. While the cheaper cigarettes increase prices by $19.2 \%$, premium cigarette prices rise by only $5.8 \%$. This heterogeneous effect can also be observed in consumption, where smokers of cheaper brands reduce consumption by $6.7 \%$ and premium brand smokers reduce smoking by only $1.0 \%$. Unlike the previous scenarios, the overall price dispersion decreases by $27.2 \%$. These findings explain the observed reduction in the price gap and revenue gap by price category.

The Federal District is the only federal unit where the aggregate tobacco tax revenue remains the same as before the tax reform. Thus, all other 26 Brazilian states increase their tax collection with the specific TET of BRL3.89 per cigarette pack. Figure 4 illustrates the relative tax revenue changes across states and regions under this scenario. It is worth noticing that the tax revenue change in scenario III is smaller than the other two scenarios.

The specific tax component tends to equalise existing tax differences across states. In other words, states where the tax burden was higher (such as the Federal District and São Paulo) experience lower tax increases than states with a smaller initial tax burden (such as Goiás, Santa Catarina and others).

Since the specific tax is the same across states and price categories, the resulting tax burden is different across states. This finding differs from the previous scenarios with ad valorem taxes only, where the tax burden is the same across states as an assumption of the simulated tax reforms.

\section{The effects of a reduction in the illicit market}

For all previous scenarios, an additional simulation is performed by relaxing the assumption that illicit trade remains constant. 


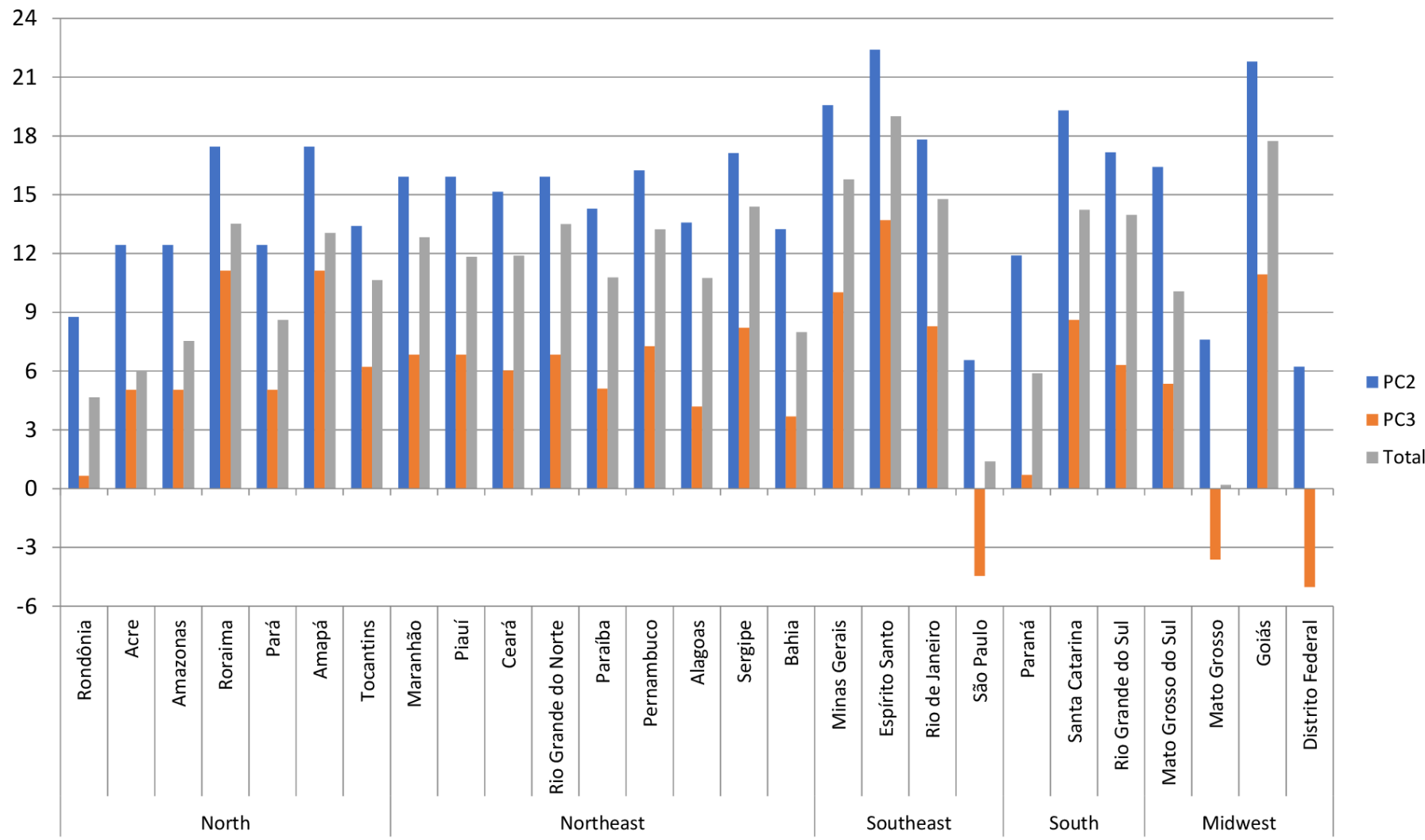

Source: Authors calculations

Figure 4 Percentage tax revenue changes by price category (PC) relative to the current tax structure-tax reform scenario III.

This simulation allows the size of the illicit market to change exogenously in a sensitivity analysis. Despite the fact that the size of the illicit market is hard to measure in practice and its estimate obviously affects the outcomes of the tax revenue simulations, it is informative to show how the illegal market might affect tax collection in the reform scenarios. Moreover, the size of the illicit cigarette market is a choice parameter because through tighter legal controls, monitoring, enforcement and many other public policies, cigarette smuggling could effectively be reduced. These measures might also increase the cost of cigarette smuggling, which would raise price and reduce consumption of illicit cigarettes, as discussed by Goodchild et al. ${ }^{11}$ Specifically, the simulation considers the effects of a $10 \%$ reduction in the illicit market. To perform this simulation, the size of the illicit cigarette market in the initial calibration that was used to replicate the observed cigarette tax collection in 2018 is exogenously reduced by $10 \%$. This reduction is then equally distributed as consumption of both, cheaper cigarettes and premium brands, increases.

Regarding the influence of the illicit market, figure 5 shows how a $10 \%$ decrease in this market would affect tax revenues in each Brazilian state. The idea is to shift cigarette consumption from the illicit to the licit market. Consequently, the government obtains tax collection gains from cigarette sales that would, otherwise, be lost. At the same time, reducing the illicit market means that the respective consumers would have to pay higher prices in the licit market, causing an overall decrease in consumption due to the consumers' price sensitivity.

The changes in tobacco tax revenue after the 10\% decrease in purchases from illicit cigarettes are quite different across the Brazilian states. In those regions where the share of the illicit market is higher, such as Mato Grosso do Sul and Acre, tax revenue increases up to $21.6 \%$. In other states like Roraima, where the share of the illicit market is currently about $20 \%$, the revenue change is still positive, but only about a fourth of that in Mato Grosso do Sul. Given the nature of the simulations, the regional differences represent a remarkable finding. If the fight against cigarette smuggling is intensified on a national scale, those states with greater access to illicit products would reap the largest relative gains.

It worth noting that the same price elasticities and cigarette prices across states and price categories are used in this simulation. Consequently, the aforementioned results are the same across scenarios I to III because both, the shifts in the share of the illegal market and the tax collection change, are expressed as percentage changes.

\section{Summary of the tax reform simulations}

The numbers in table 1 summarise the results from the three tax reform scenarios relative to the prereform baseline situation in 2018. The numbers also report the effects of a $10 \%$ reduction in the illicit cigarette market. In aggregate, the major differences relative to the baseline scenario are as follows.

1. The average tax burden and cigarette prices are higher while cigarette consumption is lower than the baseline for all simulated scenarios. The cigarette tax burden per pack increases from an average of $72.8 \%-77.85 \%$ in scenario I and to $82.95 \%$ in scenario II. These increases correspond to an additional tax revenue of BRL3.7 and BRL5.4 billion per year, respectively. In scenario III, the tax collection rises by about BRL1.1 billion per year.

2. The final average price of a 20-cigarette pack of cheaper brands would increase from BRL6.4 to either BRL7.6 or BRL9.8 in scenarios I and II, respectively. For premium 


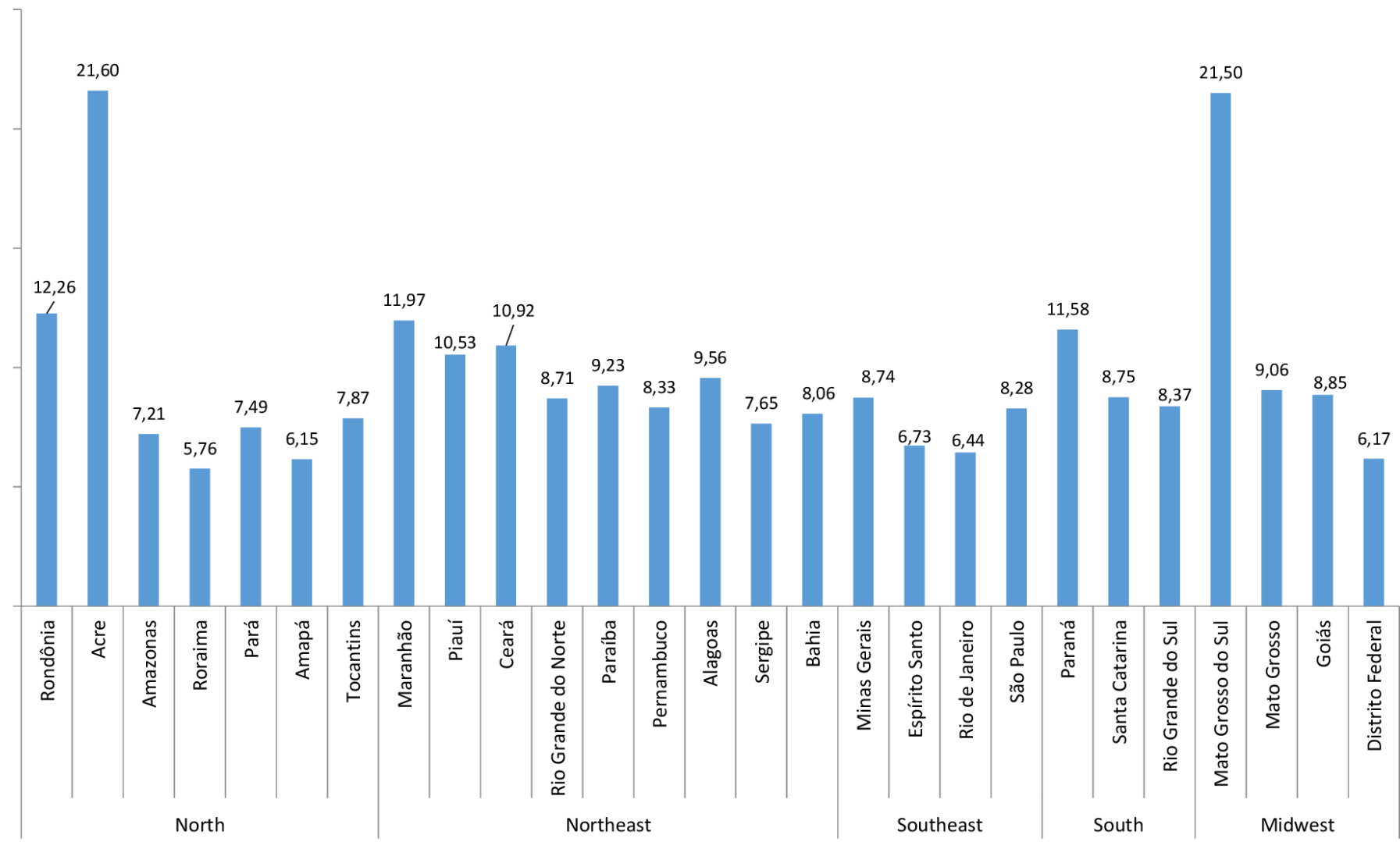

Source: Authors calculations

Figure 5 Percentage increase in tobacco tax revenue due to a $10 \%$ decrease in the illicit market.

brands, cigarette prices would rise from BRL8.7 to either BRL12.6 or BRL16.4 per pack, respectively. In scenario III, cheaper cigarettes increase prices to BRL7.63 and premium cigarettes to BRL9.17. Unlike the previous scenarios, the overall price dispersion decreases by $27.2 \%$ in scenario III.

3. In scenarios I and II, since the tax burden becomes the same across all states after the tax reform, the distribution of gains across states is uneven, but no Brazilian state experiences tax revenue losses under either scenario. For scenario III, the specific tax component tends to equalise existing tax differ-

\begin{tabular}{|ccccc}
\hline Table 1 & \multicolumn{5}{c}{ Tax reform simulations across different scenarios } \\
\hline & Baseline & Scenario I & Scenario II & Scenario III \\
\hline Tax revenue (BRL Mi. month) & 1125.49 & 1433.16 & 1576.32 & 1217.29 \\
\hline Change (baseline ref) & - & $27.34 \%$ & $40.06 \%$ & $8.157 \%$ \\
\hline Change (illicit-10\%) & $8.41 \%$ & $8.59 \%$ & $8.49 \%$ & $8.31 \%$ \\
\hline Cheaper cigarettes (PC2) & 6.40 & 7.57 & 9.83 & 7.63 \\
\hline Tax burden & $73.93 \%$ & $77.85 \%$ & $82.95 \%$ & $78.17 \%$ \\
\hline Share of tax revenue & $56.89 \%$ & $53.64 \%$ & $55.78 \%$ & $59.50 \%$ \\
\hline Consumption (\% change) & & $-9.88 \%$ & $-25.33 \%$ & $-6.69 \%$ \\
\hline Premium brands (PC3) & 8.67 & 12.65 & 16.43 & 9.17 \\
\hline Tax burden & $67.77 \%$ & $77.85 \%$ & $82.95 \%$ & $69.60 \%$ \\
\hline Share of tax revenue & $43.11 \%$ & $46.36 \%$ & $44.22 \%$ & $40.50 \%$ \\
\hline Consumption (\% change) & & $-20.85 \%$ & $-39.96 \%$ & $-1.04 \%$ \\
\hline
\end{tabular}

${ }^{*}$ Additional overall tobacco tax revenue due to a decrease of $10 \%$ in the illicit market. Scenario I is the no-tax-revenue-loss case, where no federal state loses revenue. Scenario II defines the ad valorem tax that maximises total nationwide tobacco tax revenue under the condition that no state experiences revenue losses. Scenario III includes a specific excise tax with no tax revenue loss for all federal states. The share in tax revenue refers to the percentage of revenue obtained by each price category relatively to the total cigarette tax collection.

$\mathrm{PC2}$, price category 2; $\mathrm{PC}$, price category 3. ences, with the tax burden rising proportionately more in states with lower initial tax burden.

4. A reduction of $10 \%$ in the size of the illicit cigarette market leads to an additional increase of about $8.5 \%$ in total tobacco tax revenue, which corresponds to BRL1.5, 1.6 and 1.2 billion per year in scenarios I, II and III, respectively.

5. Even under the primary condition that no federal state loses tax revenue, a tax structure with a specific component implies a lower average tax burden and lower aggregate revenue as compared with a pure ad valorem tax scheme.

\section{CONCLUSION AND POLICY RECOMMENDATIONS}

This paper investigated the effects of the Constitutional Amendment 45/2019 tobacco tax reform at the national and subnational levels in Brazil. The simulation results indicated that the tobacco tax reform should be carefully designed in order to prevent any Brazilian state from losing tax revenue, given that the tax burden per cigarette pack will be the same across all states after the reform. Any tax reform that yields a tax burden below the maximum tax burden currently observed across the states would result in a reduction of tobacco tax revenue for some states. The political viability of the reform depends on the capacity of designing a proposal that avoids any Brazilian state from losing tax revenue derived from cigarette taxation. Instead, the government could take advantage of this opportunity to increase tobacco tax revenue in times of chronic fiscal imbalance and COVID-19 pandemic crisis.

Specific taxes, whenever politically feasible, should be indexed to economic indexes, such as inflation or minimum wage. ${ }^{12}$ However, it is difficult to achieve such a tax scheme when there is a strong distaste for indexation in the society, as is the Brazilian 
case, because this was one of the major causes of the Brazilian hyperinflation during the 1980 s and 1990s. On the other hand, a specific value tax decreases the cigarette price gap, which is more effective at reducing tobacco consumption by decreasing incentives to trade down to cheaper brands. ${ }^{10} \mathrm{~A}$ minimum price policy, a mixed system, where the ad valorem tax base is charged on the retail price, can be an effective tax policy tool. The historical decrease in Brazilian smoking prevalence is a remarkable example favouring such a policy.

Finally, the simulation exercises indicate that it is worth intensifying the fight against cigarette smuggling nationwide as a relevant public policy to reduce cigarette consumption and raise tax revenue. The additional money might be used to reduce the country's fiscal imbalance and to pay for health costs and social transfers to the most vulnerable families during these difficult times of the COVID-19 pandemic crisis.

It is worth mentioning, however, that the analysis has some caveats that prevent the conclusions from be taken as policy suggestions. It is based on a partial equilibrium model focused on the tobacco market, which does not account for either dynamic effects over time or a general equilibrium framework. Even though the share of the tobacco segment in the total output is negligible when compared with other economic sectors, it might be desirable to take into account the interdependence among sectors in a dynamic stochastic general equilibrium model of the

\section{What this paper adds}

\section{What is already known on this subject}

- Constitutional amendment bills are being considered by the Congress to reform the Brazilian tax system, mainly directed at consumption taxes. It may impact the tobacco taxation system which is an essential part of the successful Brazilian tobacco control public policy. However, it is unclear how the tax reform will impact tobacco taxes.

\section{What this paper adds}

- We came to the conclusion that a tobacco tax reform along the lines of the proposed Constitutional Amendment Bill $45 / 2019$ has the potential to increase the total tax collection and reduce fiscal imbalance.

- We found that if the proposed reform is implemented, the cigarette tax burden would become the same across all Brazilian states; and that in order to avoid decreasing tobacco tax revenues in any state, the proposed reform must increase the cigarette tax burden to about $83 \%$.

- We concluded that after the proposed tobacco tax reform, the average consumer price would increase to BRL9.8 per low-cost cigarette pack and BRL16.4 per premium-brand pack, while smoking would decrease by $25.3 \%$ and $39.9 \%$ for these price categories, respectively. That would result in additional tax revenues of BRL5.4 billion per year.

- We evaluate that efforts to reduce illicit trade would reduce smoking and increase revenues. A $10 \%$ reduction in the size of the illicit cigarette market would lead to an increase of $8.5 \%$ in the total tobacco tax revenue, which corresponds to about BRL1.6 billion of extra revenue per year.

- A tobacco tax reform coupled with a reduction in the illicit cigarette market has the potential to bring multiple benefits to the Brazilian society, including additional tax revenues for covering healthcare costs during the COVID-19 pandemic crisis and reducing the chronic fiscal imbalance in the country. economy. Despite the intrinsic complexity, this approach would allow one to make consistent policy recommendations about alternative scenarios for tobacco tax reform in the Brazilian economy. Such improvements in the current model are left as suggestions for further research.

Acknowledgements The authors thank Frank Chaloupka, Jeff Drope, German Rodriguez Iglesias, Michal Stoklosa and Erika Siu for their helpful comments and suggestions.

Contributors All coauthors worked on the research and paper drafting.

Funding This research (grant number 17409) was funded by the University of Illinois at Chicago (UIC) Institute for Health Research and Policy to conduct economic research on tobacco taxation in Brazil. UIC is a partner of the Bloomberg Initiative to Reduce Tobacco Use.

Disclaimer The views expressed in this document cannot be attributed to, nor do they represent, the views of UIC, the Institute for Health Research and Policy, or Bloomberg Philanthropies.

Competing interests None declared.

Patient consent for publication Not required.

Provenance and peer review Not commissioned; externally peer reviewed.

Data availability statement Data are available in a public, open access repository. The public data used in the paper are: 1) National Household Sample Survey (PNAD) of 2008, available at https://www.ibge.gov.br/estatisticas/sociais/ educacao/9127-pesquisa-nacional-por-amostra-de-domicilios.html? edicao=9128\& $\mathrm{t}=$ downloads or at https://ftp.ibge.gov.br/Trabalho_e_Rendimento/Pesquisa_ Nacional_por_Amostra_de_Domicilios_anual/2008/Documentacao_pnad2008/ Dados.zip; 2) National Health Survey (PNS) of 2013, available at https://www. ibge.gov.br/estatisticas/sociais/saude/9160-pesquisa-nacional-de-saude.html\&t= downloads or at https://ftp.ibge.gov.br/PNS/2013/Microdados/Dados/PNS_2013. zip; 3) Risk Factor Surveillance and Protection for Chronic Diseases by Telephone Survey (VIGITEL), which is performed annually, available at http://svs.aids.gov.br/ download/Vigitel/, for the year 2018 used in the text see at https://portalarquivos2. saude.gov.br/images/pdf/2019/julho/25/vigitel-brasil-2018.pdf; 4) Cigarette tax revenue at national level, Federal Revenue Service (Brazil), available at https://www. gov.br/receitafederal/pt-br; 5) Population per state - Brazilian Institute of Geography and Statistics - IBGE - available at https://www.ibge.gov.br/estatisticas/sociais/ populacao.html.

\section{ORCID iDs}

Jose Angelo Divino http://orcid.org/0000-0001-7359-7539

Philipp Ehrl http://orcid.org/0000-0002-6661-8976

Osvaldo Candido http://orcid.org/0000-0002-4850-6989

Marcos Aurelio Pereira Valadao http://orcid.org/0000-0002-9301-3366

\section{REFERENCES}

1 José BPdeS, Corrêa RdeA, Malta DC, et al. Mortality and disability from tobaccorelated diseases in Brazil, 1990 to 2015. Rev Bras Epidemiol 2017;20Suppl 01:75-89.

2 Brazilian Health Ministry. Vigitel Brasil 2018: Vigilância de fatores de risco E proteção para doenças crônicas POR inquérito telefônico: estimativas sobre frequência $E$ distribuição sociodemográfica de fatores de risco E proteção para doenças crônicas nas capitais DOS 26 estados brasileiros E no Distrito federal em 2018. Brasília: Ministério da Saúde, 2019. https://portalarquivos2.saude.gov.br/images/pdf/2019/ julho/25/vigitel-brasil-2018.pdf

3 Brazilian Institute of Geography and Statistics (IBGE). National household sample survey (PNAD), 2008. Available: https://ftp.ibge.gov.br/Trabalho_e_Rendimento/ Pesquisa_Nacional_por_Amostra_de_Domicilios_anual/2008/Documentacao_ pnad2008/Dados.zip

4 Brazilian Institute of Geography and Statistics (IBGE). Pesquisa Nacional de Saúde (PNS) 2013: Percepção do estado de saúde, estilos de vida E doenças crônicas Brasil, Grandes Regiões E Unidades dA Federação. Rio de Janeiro: IBGE, 2014. https://ftp. ibge.gov.br/PNS/2013/Microdados/Dados/PNS_2013.zip

5 Divino JA, Ehrl P, Candido O, et al. An extended cost-benefit-analysis of tobacco taxation in Brazil. unpublished manuscript (research report). 2019. Catholic University of Brasilia and University of Chicago at Illinois.. Available: https://tobacconomics.org/ research/an-extended-cost-benefit-analysis-of-tobacco-taxation-in-brazil/

6 Ribeiro L, Pinto V. Accelerating Effective Tobacco Taxes in Brazil: Trends and Perspectives. Red Sur Country Studies Series Tobacco Taxes in Latin America Country Study N³/2019, 2019.

7 Szklo A, Iglesias RM, Carvalho de Souza M, et al. Trends in illicit cigarette use in Brazil estimated from legal sales, 2012-2016. Am J Public Health 2018;108:265-9.

8 Odair RO, Gobetti SW. Reforma Tributária E Federalismo fiscal: uma Análise das Propostas de Criação de um novo Imposto sobre O Valor Adicionado para O Brasil. 
Texto para Discussão n 2530, Instituto de Pesquisa Econômica Aplicada - IPEA, 2019. Available: http://repositorio.ipea.gov.br/bitstream/11058/9596/1/TD 2530.PDF

9 Ministry of Justice and Public Security, Brazil. RELATÓRIO final No 1/2019/CNCPDPI/ SE, processo: 08007.003961/2019-36, 2019. Available: https://actbr.org.br/uploads/ arquivos/Relato\%CC\%81rio-Final-GT-Moro-\%281\%29.pdf

10 WHO (World Health Organization). Technical manual on tobacco Tax administration. Reprinted in 2011. Geneva: World Health Organization, 2010. https://apps. who.int/ iris/handle/10665/44316
11 Goodchild M, Paul J, Iglesias R, et al. Potential impact of eliminating illicit trade in cigarettes: a demand-side perspective. Tob Control 2020. doi:10.1136/ tobaccocontrol-2020-055980. [Epub ahead of print: 03 Nov 2020].

12 Rodriguez-Iglesias G, Blecher E. Tax Structures are Key in Raising Tobacco Taxes \& Revenues. A Tobacconomics Policy Brief. Chicago, IL: Tobacconomics, Health Policy Center, Institute for Health Research and Policy, University of Illinois at Chicago, 2018. https://tobacconomics.org/research/tax-structures-are-key-in-raising-tobacco-taxesrevenues/ 